\title{
IN VITRO EFFICACY OF FUNGICIDES AND PLANT EXTRACTS ON THE GROWTH OF COLLETOTRICHUM GLOEOSPORIOIDES (PENZ.) PENZ. \& SACC. AND SCLEROTIUM ROLFSII SACC. THE CAUSAL ORGANISMS OF ANTHRACNOSE AND SOFT ROT OF JUTE
}

\author{
Sarowar Hosen, Shamim Shamsi and MA Bashar* \\ Department of Botany, University of Dhaka, Dhaka-1000, Bangladesh \\ Key words: Efficacy, Fungicides, Plant extracts, Colletotrichum gloeosporioides, \\ Sclerotium rolfsii, Jute
}

Jute is the most important cash crop of Bangladesh. It is obtained mainly from Corchorus capsularis L. and C. olitorius L. The contribution of jute sector to economy of Bangladesh is enormous. But diseases play a major role for the severe yield loss of jute. According to Ahmed(1) $24.5 \%$ loss in yield of fiber occurred owing to different diseases. Among the destructive diseases of jute, anthracnose and soft rot have significant impact on the yield of the crop. Anthracnose affected plants yield for poor quality fiber, mostly knotty in nature with adherent barks which resists the retting.

Various workers in different countries evaluated the efficacy of various fungicides against Colletotrichum spp. and S. rolfsii under laboratory and field conditions ${ }^{(2-9)}$. Very few works have been done for the control of anthracnose and soft rot diseases of jute by fungicides and plant extracts. Therefore, the present investigation was ascertained to investigate the inhibitory effect of extracts of various plant species and fungitoxicity of fungicides on the mycelial growth of C. gloeosporioides and S. rolfsii under in vitro conditions.

Jute plants with anthracnose and soft rot symptoms were collected from selected fields of Manikganj (BJRI) and research field of the Botanical Garden, Dhaka University to record the prevalence of diseases during May, 2014 to November, 2014. Jute samples were collected in separate sterile polyethylene bags, labeled properly and then brought to the laboratory for isolating associated pathogenic fungi following "Tissue planting method" on PDA medium.

Five fungicides, viz., Bavistin DF, Capvit 50 WP, Dithane M-45, Greengel 72 WP and Tilt 250 EC were collected from the Krishi Upokoron Biponi Kendro, Khamarbari, Farmgate, Dhaka. The fungicides which were effective at $500 \mathrm{ppm}$ for controlling the test pathogens were further tested at 100, 200 and 400 ppm following poisoned food technique ${ }^{(10)}$.

*Corresponding author: ‘botanybashar@yahoo.com> 
For in vitro effect of six plants extract, viz., Allium sativum, Azadirachta indica, Citrus limon, C. grandis, Datura metel and Zingiber officinale were selected on the radial growth of test pathogens. The radial growths of the test pathogen colonies were measured after 3 days in case of S. rolfsii while 7 days in case of $C$. gloeosporioides. The per cent growth inhibition of each test pathogen was calculated using the formula described by Bashar ${ }^{(11)}$. The results were statistically analyzed by t-test following Steel and Torrie ${ }^{(12)}$.

Table 1 shows that all the fungicides inhibited the growth of the test fungi partially or completely at $500 \mathrm{ppm}$ concentration. Amongst them all the fungicides showed the complete growth inhibition of C. gloeosporioides while Dithane M-45, Greengel 72 WP and Tilt 250 EC showed the complete inhibition of growth of $S$. rolfsii at $500 \mathrm{ppm}$. These fungicides were again tested in 100, 200 and $400 \mathrm{ppm}$ to find out their minimal requirement of concentration.

Table 1. Fungitoxicity of fungicides against Colletotrichum gloeosporioides and Sclerotium rolfsii at $500 \mathrm{ppm}$.

\begin{tabular}{lcc}
\hline \multirow{2}{*}{$\begin{array}{l}\text { Name of } \\
\text { fungicides }\end{array}$} & \multicolumn{2}{c}{$\%$ inhibition of radial growth of the test fungi } \\
\cline { 2 - 3 } & C. gloeosporioides & S. rolfsii \\
\hline Bavistin DF & $100^{\mathrm{a}}$ & $30.50^{\mathrm{b}}$ \\
Capvit 50 WP & $100^{\mathrm{a}}$ & $42.50^{\mathrm{b}}$ \\
Dithane M-45 & $100^{\mathrm{a}}$ & $100^{\mathrm{a}}$ \\
Greengel 72 WP & $100^{\mathrm{a}}$ & $100^{\mathrm{a}}$ \\
Tilt 250 EC & $100^{\mathrm{a}}$ & $100^{\mathrm{a}}$ \\
\hline
\end{tabular}

${ }^{\mathrm{a}}$ and ${ }^{\mathrm{b}}$ Indicate significance at $\mathrm{p}=0.001$ and 0.01 , respectively.

Out of five fungicides, complete inhibition of the growth of the C. gloeosporioides was observed with Bavistin DF, Greengel 72 WP and Tilt 250 EC at 100, 200 and 400 ppm, respectively (Fig. 1). On the other hand, complete inhibition of the growth of $S$. rolfsii was observed only with Greengel 72 WP at 100, 200 and 400 ppm (Fig. 2). It is also clear from the results that the per cent growth inhibition of the test pathogens gradually increased with the increase in concentration of the fungicides.

In accordance with the present study, Sharma and Verma ${ }^{(4)}$ reported that Bavistin check the growth of $C$. gloeosporioides Penz., causal agent of anthracnose of mango (Mangifera indica L.), completely at $100 \mathrm{ppm}$. In contrast to the present study, Yaqub and Shahzad(5) observed that Dithane M-45 and Sancozeb were most effective in inhibition of the growth of $S$. rolfsii. The same fungicides also showed different effects on different pathogens in the present investigation due to the selection of different test pathogens. 


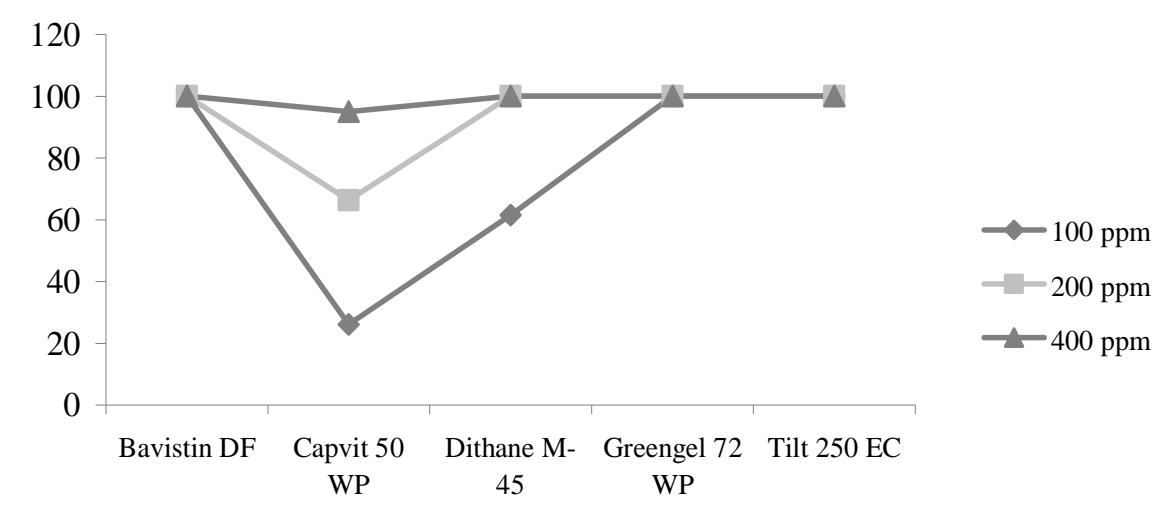

Fig. 1.Per cent inhibition of radial growth of Colletotrichum gloeosporioides owing to fungicides at different concentrations.

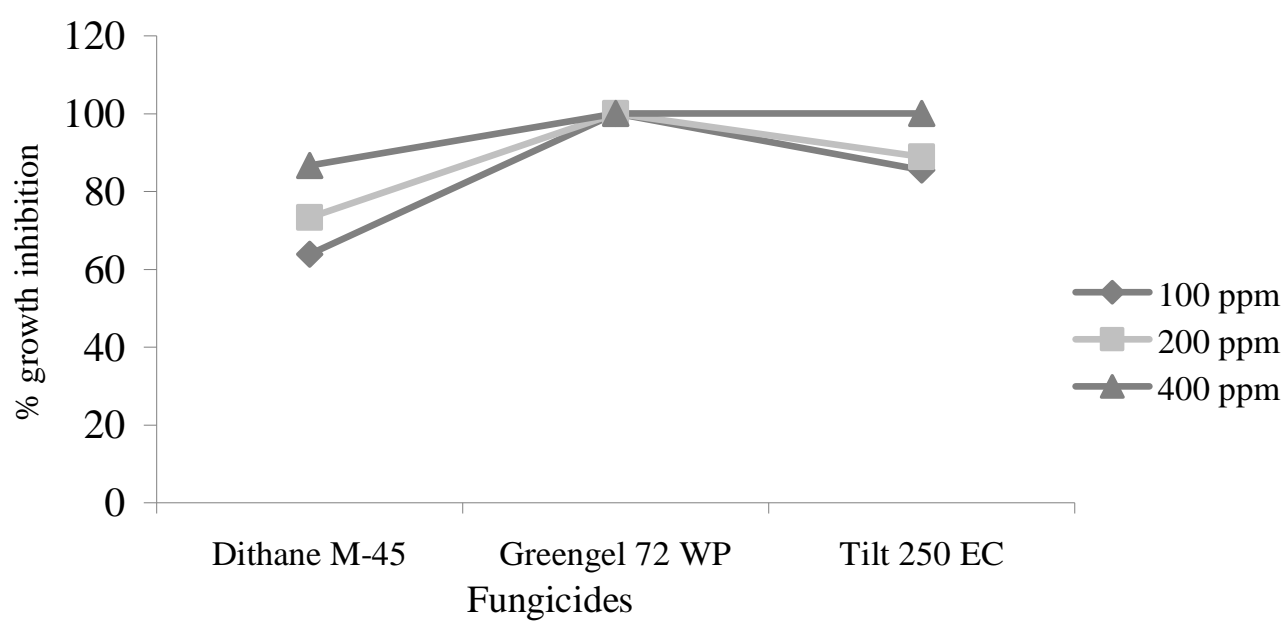

Fig. 2. Per cent inhibition of radial growth of Sclerotium rolfsii owing to fungicides at different concentrations.

Results of plant extracts on the radial growth of Colletotrichum gloeosporioides and Sclerotium rolfsii are presented in Figs 3 - 4. All the plant extracts showed varied degrees of growth inhibition of the pathogens at different concentrations.

Out of the six plant extracts, Allium sativum showed 100\% radial growth inhibition of C. gloeosporioides at $20 \%$ concentration followed by Citrus limon (75.25\%), Datura metel (73.19\%) and Azadirachta indica $(70.05 \%$. The per cent inhibition of the pathogens increases with the increase of the concentration of the plant extracts in culture medium. 
The highest inhibition of the growth of Sclerotium rolfsii was observed with Allium sativum at $20 \%$ concentration followed by Citrus limon (80.67\%) and Azadirachta indica (55.56\%). The per cent inhibition of the pathogens increases with the increase of the concentration of the plant extracts in culture medium.

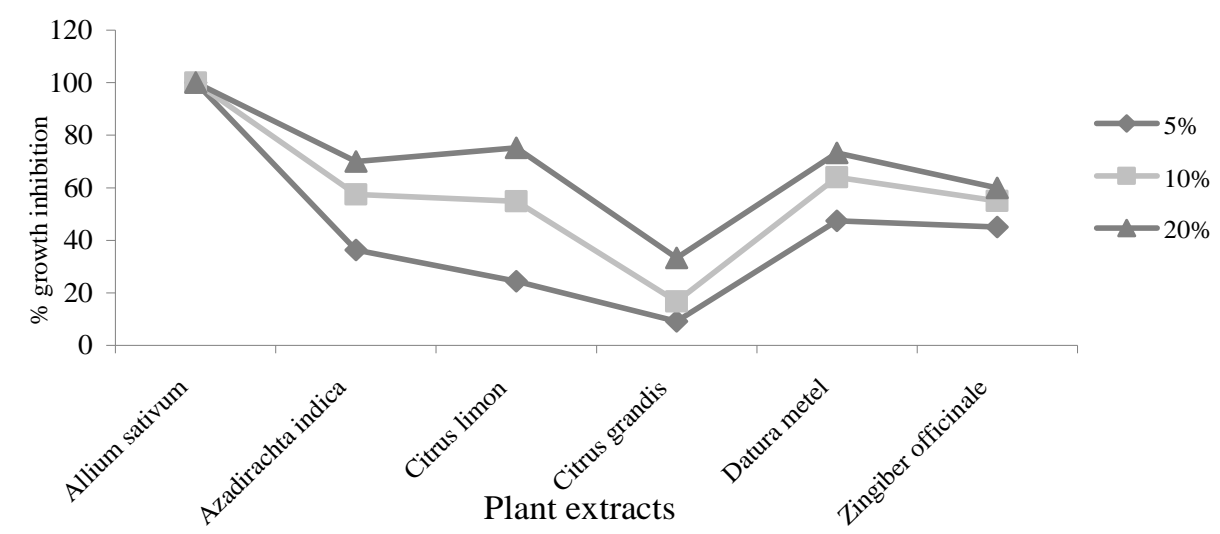

Fig. 3. Per cent inhibition of radial growth of Colletotrichum gloeosporioides owing to plant extracts at different concentrations.

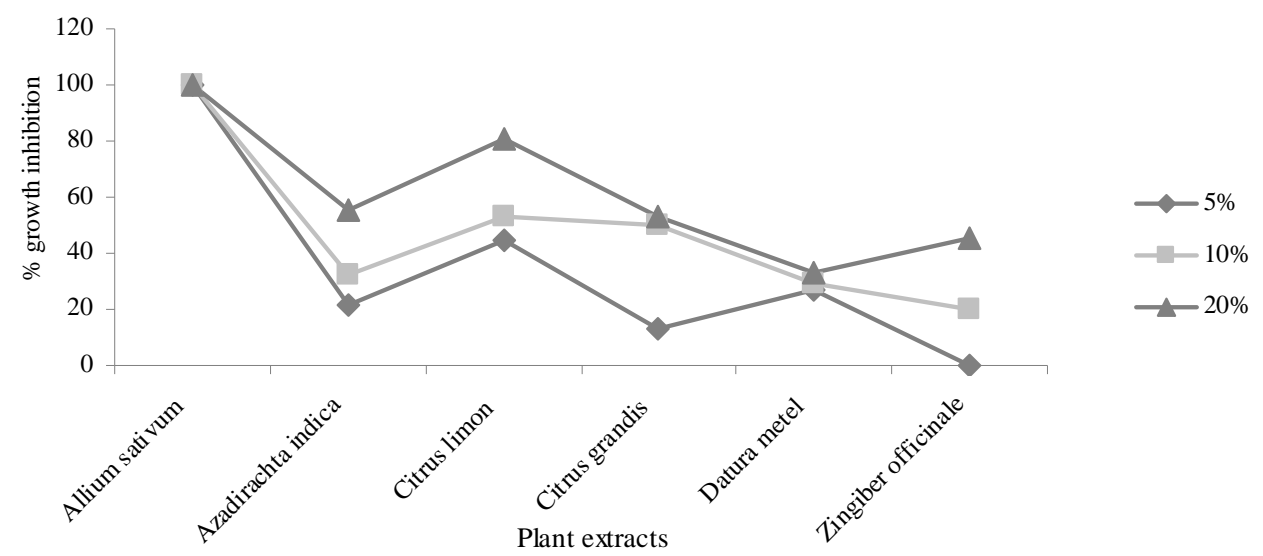

Fig. 4. Per cent inhibition of radial growth of Sclerotium rolfsii owing to plant extracts at different concentrations.

Ogbebor et al.(13) reported that extract of Allium sativum L. exhibited total inhibitory effects on the mycelial growth of C. gloeosporioides, causal organism of rubber (Hevea brasiliensis Muell. Arg.) leaf spot. Bashar et al.(10) reported that the plant extract of Azadirachta indica showed $95.50 \%$ growth inhibition of Fusarium oxysporum. Farooq et al.(14) reported that the plant extract of Azadirachta indica showed $73.80 \%$ growth inhibition 
of S. rolfsii. The same plant extracts also showed different effects on different pathogens in the present investigation due to the selection of different test pathogens.

The present study suggests that Bavistin DF, Greengel 72 WP and Tilt 250 EC may be exploited in vivo to control the test fungi associated with anthracnose while Greengel 72 WP for soft rot diseases of jute. Out of six plant extracts, Allium sativum can be used as promising botanical fungicide for further testing against anthracnose and soft rot diseases in jute.

\section{References}

1. Ahmed QA 1968. Diseases of jute in East Pakistan. Jute and Jute Fabrics 7: 147-151.

2. Acharya A and JN Das 1995. Control of anthracnose of betel vine by fungicidal chemicals. Current Agricul. Res. 8(2): 58-60.

3. Bhanumathi A and VR Rai 2007. Leaf blight of Azadirachta indica and its management in vitro. African J. Agricul. Res. 2 (10): 538-543.

4. Sharma A and KS Verma 2007. In vitro cross pathogenicity and management of Colletotrichum gloeosporioides causing anthracnose of mango. Ann. Plant Prot. Sci. 15(1): 186-188.

5. Yaqub F and S Shahzad 2006. Effect of fungicides on in vitro growth of Sclerotium rolfsii. Pak. J. Bot. 38(3): 881-883.

6. Sharmin S and S Shamsi 2013. In vitro control of five pathogenic fungi isolated from groundnut (Arachis hypogaea L.). J. Asiat. Soc. Bangladesh, Sci. 39(1): 27-33.

7. Bashar MA and M Chakma 2014. In vitro control of Fusarium solani and F. oxysporum the causative agent of brinjal wilt. Dhaka Univ. J. Biol. Sci. 23(1): 53-60.

8. Bashar MA, R Akter and KS Hossain 2015. Potential fungicides and plant extracts against fusarial wilt of brinjal. Dhaka Univ. J. Biol. Sci. 24(2): 209-213.

9. Chowdhury P, MA Bashar and S Shamsi 2015. In vitro evaluation of fungicides and plant extracts against pathogenic fungi of two rice varieties. Bangladesh J. Bot. 44(2): 251-259.

10. Pennycook SR and JB Corbin 1970. A preliminary laboratory assessment of fungicides for the control of Sclerotinia scleretiorum (LIB) DBY. Tone 16: 21-30.

11. Bashar MA 1992. Laboratory evaluation of some pesticides on Fusarium oxysporum f. sp. ciceri causing wilt of chickpea. Bangladesh J. Bot. 21(1): 157-159.

12. Steel RGD and JH Torrie 1960. Principles and Procedures of Statistics. MacGraw Hill Book Co., New York. pp. xvi +481.

13. Ogbebor NO, AT Adekunleand DA Enobakhare 2007. Inhibition of Colletotrichum gloeosporioides (Penz.) Sacc. causal organism of rubber (Hevea brasiliensis Muell. Arg.) leaf spot using plant extracts. African Journal of Biotechnology 6 (3): 213-218.

14. Farooq MA, U Iqbal, SM Iqbal, R Afzal and ARasool 2010. In vitro evaluation of different plant extracts on mycelial growth of Sclerotium rolfsii, the cause of root rot of sugar beet. Mycopath. 8(2): 81-84. 